\title{
Influence of maize germ oilcake on processes of wheat dough ripening and bread quality and nutritional value
}

\author{
Galyna Stepankova, Svitlana Oliinyk, \\ Valeriy Mykhaylov, Olga Neklesa \\ Kharkiv State University of Food Technology and Trade, Kharkiv, Ukraine
}

Keywords:

Bread

Maize

Germ

Oilcake

Ripening

Article history:

Received 16.10.2016

Received in revised

form 16.02.2017

Accepted 30.03.2017

Corresponding

author:

Galyna Stepankova

E-mail:

Stepankova_galina @ukr.net

DOI: $10.24263 / 2304-$

974X-2017-6-1-5

\section{Abstract}

Introduction. The influence of maize germ oilcake on processes of wheat dough final ripening, as well as on bread nutritional and biological value was studied.

Materials and methods. The following materials were used in the studies: maize germ oilcake, wheat flour of the first quality, bakery pressed yeast, salt, potable water. The intensity of ethanol fermentation was determined on the basis of gas production rate in the dough and intensity of lactic-acid fermentation - on the basis of change of its titratable acidity. The bread quality parameters, as well as its nutritional value were studied by generally accepted methods.

Results and their discussion. The results of experimental studies have shown that substitution of wheat flour with 10.0 to $20.0 \%$ of maize germ oilcake promotes intensification of acid accumulation and gas production in the dough, which is the basis for shortening the interval of its ripening by 6.0 to $17.0 \%$. At the same time, reduction of the dough volume is observed as the additive dosage is increased. The bread manufactured by straight-dough method with addition of the maize germ oilcake has a pleasant corn aftertaste and flavor, more intensively colored crust and soft part, higher moisture and titratable acidity parameters, in comparison with the check sample. Introduction of more than $15 \%$ of the additive leads to a substantial decrease of porosity parameters and bread specific volume that makes it impossible to recommend its greater dosage in case of straight method of bread manufacture.

The bread manufactured with the use of $15 \%$ of the maize germ oilcake is characterized by a higher content of lysine, cystine, methionine and threonine unsubstituted amino acids, higher content of dietary fibers by 1.7 times, vitamins $\mathrm{B}_{1}$ - by 1.4 times, $\mathrm{E}$ - by 3.0 times, magnesium by 2.2 times, iron - by 2.3 times.

Conclusion. Use of $15 \%$ of maize germ oilcake in case of straight method of bread manufacture makes it possible to obtain the products of high quality and increased nutritional and biological value. 


\section{Introduction}

One of the global problems of today is propagation among population of the most countries of alimentary diseases caused by unbalanced diet. The modern method of its solution consists in increase of nutritional and biological value of every-day consumption products, including breadstuffs. It is known that traditional bread types having a high energy value are characterized by unbalanced amino acid composition, low content of dietary fibers, low content of many vitamins and mineral substances. Therefore, an important task of bread-making branch consists in forming the range of breadstuffs enriched with physiologically functional ingredients. A promising way of task-oriented change of breadstuff chemical composition is provided by use of in breadstuff technology of products obtained in flour-milling and fat-and-oil industries and during cereals manufacture.

To increase the nutritional and biological value of bread, we proposed to use maize germ oilcake being a byproduct in technology of maize oil manufacture. The maize germ oilcake comprises a finely dispersed powder characterized by a high content of protein $(20.0 \%)$, starch $(25 \%)$, as well as dietary fibers $(22.5 \%)$ which are mainly represented by hemicelluloses and cellulose. It contains $29.7 \mathrm{mg} / 100 \mathrm{~g}$ of vitamin E, $0.73 \mathrm{mg} / 100 \mathrm{~g}$ of vitamin $\mathrm{B}_{1}$ and $5.6 \mathrm{mg} / 100 \mathrm{~g}$ of vitamin $\mathrm{PP}$, as well as considerable quantity of mineral substances, such as calcium, magnesium, phosphorus and iron [1].

It is known that use of enriching raw materials in bread technology influences not only on nutritional value of finished products but also on progress of processes of dough ripening, including microbiological ones [2-5]. The microbiological processes are one of key factors determining bread quality. Intensity of ethanol fermentation largely determines volume of dough pieces and finished products, and lactic-acid fermentation products play an important role in forming organoleptic, physical and chemical properties of dough and bread.

The objective of these studies, which results are presented below, was determination of influence of the maize germ oilcake on progress of microbiological processes taking place during ripening of wheat dough, as well as on parameters of bread quality and its nutritional and biological value.

\section{Materials and methods}

In our studies, we used maize germ oilcake (Table 1), wheat flour, pressed bakery yeast, food-grade cooking salt and potable water.

To obtain the check sample of bread, we kneaded $44 \%$ moisture dough of wheat flour with addition of $3.0 \%$ of pressed bakery yeast, $1.5 \%$ of salt, as well as potable water. To obtain the test samples, the maize germ oilcake was introduced in the stage of dough kneading in dry condition in quantity of 10.0, 15.0 and $20.0 \%$ instead of flour. With consideration of the data on water-absorbing capacity of dough in case of introduction of additive [6] obtained earlier, its moisture contents in the test samples were 44.8, 45.3 and $45.7 \%$, respectively. All dough samples were subjected to ripening. The ripened dough was divided to $280 \mathrm{~g}$ pieces, which were rounded, placed in baking tins, held there for (30 to $40) \times 60 \mathrm{~s}$ at a temperature of $37^{\circ} \mathrm{C}$ and baked for $30 \times 60 \mathrm{~s}$ at a temperature of 180 to 220 ${ }^{\circ} \mathrm{C}$. 
Quality parameters of maize germ oilcake

\begin{tabular}{|l|c|}
\hline \multicolumn{1}{|c|}{ Parameter } & Description of parameter \\
\hline Appearance & Finely dispersed dry powder \\
\hline Taste & Pleasant sweetish corn taste \\
\hline Flavor & Pleasant corn flavor \\
\hline Color & Light yellow \\
\hline Titratable acidity, deg. & 7.8 \\
\hline Moisture, \% & 13.8 \\
\hline
\end{tabular}

The influence of maize germ oilcake on dough ripening microbiological processes was studied by change of parameters of gas production rate and titratable acidity in the dough, as well as by change of its volume during fermentation.

The gas production rate in the dough was determined with the help of Iago-Ostrovsky instrument [7]. To determine quantity of gas released during fermentation, a $500 \mathrm{~cm}^{3}$ conical flask with $100 \mathrm{~g}$ of dough was put into thermostat at a temperature of $30{ }^{\circ} \mathrm{C}$. The flask with dough was closer with rubber plug having a tube connecting it with other flask filled with sodium chloride saturated solution. The quantity of gas released during fermentation corresponds to quantity of displaced sodium chloride saturated solution.

To determine change of volume during fermentation, $50 \mathrm{~g}$ of kneaded dough was placed in $250 \mathrm{~cm}^{3}$ graduated cylinder previously lubricated with oil, which was held in thermostat at a temperature of $30{ }^{\circ} \mathrm{C}$. The initial volume of dough and its changes during fermentation were recorded.

The titratable acidity was determined by method described in [7]. For this purpose, $5 \mathrm{~g}$ of dough was rubbed with $50 \mathrm{~cm}^{3}$ of water, 3-5 drops of $1 \%$ phenolphthalein solution were added, and then the obtained solution was titratable with $0.1 \mathrm{~mol} / \mathrm{dm}^{3}$ solution of sodium hydroxide till appearance of pink color not disappearing for one minute. The acidity was calculated with the use of the following formula:

$$
X=\frac{a \cdot 100}{G \cdot 10} \cdot K
$$

where $\mathrm{X}$ - titratable acidity, deg.;

a - quantity of milliliters of $0.1 \mathrm{~mol} / \mathrm{dm}^{3}$ solution of $\mathrm{NaOH}$ used for titration;

$\mathrm{G}$ - mass of accurately weighed substance, $\mathrm{g}$;

10 - conversion from $0.1 \mathrm{~mol} / \mathrm{dm}^{3}$ to $1 \mathrm{~mol} / \mathrm{dm}^{3}$ of alkali solution;

$\mathrm{K}$ - correction coefficient for alkali titer.

The assessment of organoleptic parameters of product quality (appearance, color, condition of crust, condition of soft part, taste and flavor) was carried out after the bread was fully cooled [8]. The physical and chemical parameters of quality, such as moisture, specific volume and porosity, were determined with the use of generally accepted procedures [9-11].

For determination of bread titratable acidity, $25 \mathrm{~g}$ of its soft part was placed in a flask having capacity of $500 \mathrm{~cm}^{3}$, where $250 \mathrm{~cm}^{3}$ of water having temperature of $20{ }^{\circ} \mathrm{C}$ was added. The flask was closed with plug and vigorously shaken for $2 \times 60 \mathrm{~s}$, settled for $10 \times 60$ $\mathrm{s}$, shaken for $2 \times 60 \mathrm{~s}$ and settled again for $8 \times 60 \mathrm{~s}$. Then the solution was filtered, $50 \mathrm{~cm}^{3}$ of the filtrate were taken with pipette and transferred in two $150 \mathrm{~cm}^{3}$ conical flasks, $2-3$ drops 
of phenolphthalein solution were added, and titration was carried out with $0.1 \mathrm{~mol} / \mathrm{dm}^{3}$ solution of sodium or potassium hydroxide till appearance of light pink color not disappearing for $1 \times 60 \mathrm{~s}$ [11].

The titratable acidity was calculated with the use of the following formula:

$$
K=2 \cdot v,
$$

where $v$ is the volume of $0.1 \mathrm{~mol} / \mathrm{dm}^{3}$ solution of sodium or potassium hydroxide lost for titration.

The content of protein in bread was determined by modified Kjeldahl's method, content of certain amino acids - by method of ion-exchange liquid-column chromatography on automatic analyzer of amino acids T339 (Mikrotechna, Prague) [12], fat content and total quantity of carbohydrates - by method presented in [13]. The total content of dietary fibers was determined by fermentative methods [12], and that of tanning substance - by titrimetric methods [14], quantity of vitamin $B_{1}$ - by special method described in [15], that of vitamin $\mathrm{E}$ - by thin-layer chromatography method with a high resolution [16], quantity of mineral substances - by atomic emission spectrometry [17].

The protein amino acid score (AC, \%) was calculated with the use of the following formula:

$$
A C=\frac{P}{P_{i}} \cdot 100,
$$

where $P$ - the content of certain amino acid in $100 \mathrm{~g}$ of protein of studied product, $\mathrm{mg} / \mathrm{g}$;

$P_{i}$ - the content of this amino acid in «ideal protein» according to the data of $\mathrm{FAO} / \mathrm{WHO},(\mathrm{mg} / \mathrm{g})[9]$.

\section{Results and their discussion}

The results of determination of influence of maize germ oilcake on gas production process in the wheat dough are presented in Figure 1.

From the data presented, it can be seen that its addition in the entire studied range causes intensification of ethanol fermentation in the dough. In the first stage of fermentation, easily accessible sugars contained in the dough are fermented. Reduction of their quantity in the system leads to decrease of gas production rate. From the Figure, it can be seen that this phenomenon is observed in the check sample after $70 \times 60 \mathrm{~s}$ from the beginning of our experiment, while in the test samples - by $(10$ to 30$) \times 60 \mathrm{~s}$ earlier.

Accumulation in the dough of sufficient quantity of maltose as a result of starch amylolysis and also yeast adaptation to its use leads to intensification of ethanol fermentation, which results in increase of rate of carbon dioxide formation to be continued until deficiency of maltose in the dough occurs. Further reduction of gas production rate evidences expediency of completion of dough ripening stage. The maximum gas production rate in the dough samples with added maize germ oilcake takes place in $(150$ to 170) $\times 60 \mathrm{~s}$ from the beginning of experiment, and in the check sample - in $180 \times 60 \mathrm{~s}$, which comprises the precondition for reduction of dough ripening duration by 6 to $17 \%$ in case of introduction of the additive. 


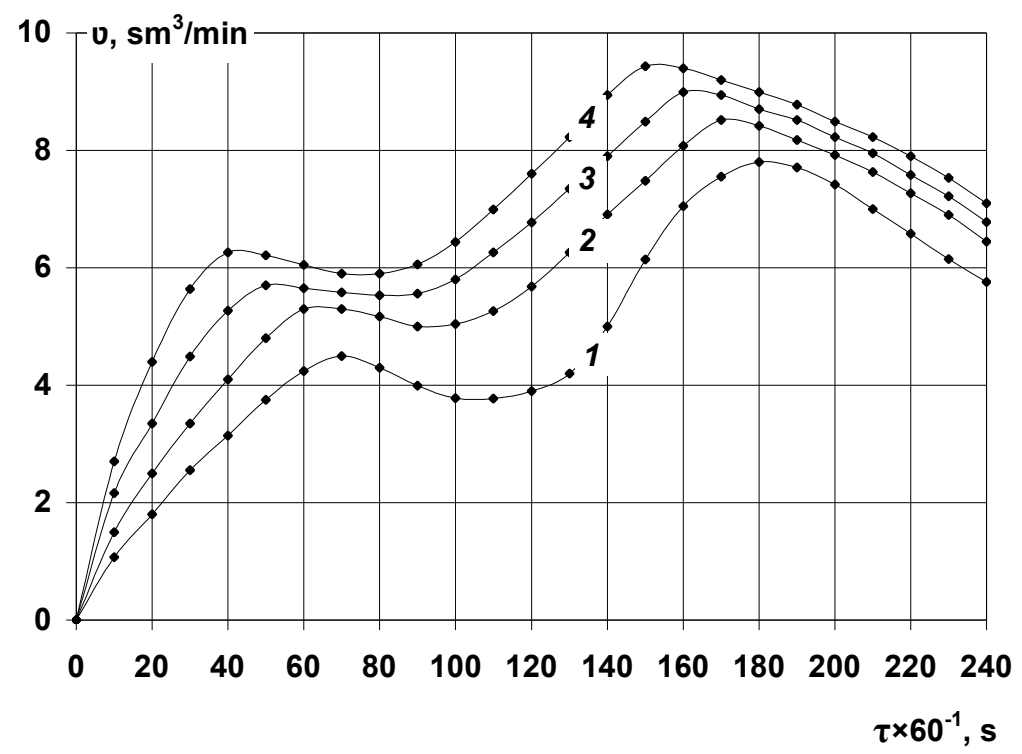

Figure 1. Change of gas production rate in dough with maize germ oilcake: 1 - without additive (check sample);

$2,3,4-$ with introduction of $10.0 ; 15.0$ and $20.0 \%$ of additive, respectively

Intensification of gas production in the dough in case of addition of maize germ oilcake is connected, in our opinion, with high content in it of mono- and disaccharides, amino acids, vitamins and mineral substances, which are a nutrient medium for bakery yeast and promote activation of its vital activity. Besides, maize starch is more accessible for amylolytic enzymes, in comparison with wheat one, which promotes more intensive accumulation of maltose in the dough.

The results of study of influence of the tested additive on change of the dough volume during ripening are presented in Figure 2.

It can be see from the Figure that addition of maize germ oilcake in the entire test interval promotes reduction of dough volume in relation to the check sample. For example, in case of decreasing the duration of ripening dough with maize germ oilcake by (10 to $30) \times 60 \mathrm{~s}$, the dough volume is lesser by 6.0 to $10.5 \%$, in relation to check sample. Such trend is rather expected in case of substitution of wheat flour with gluten-free raw material, which results in loss of $\mathrm{CO}_{2}$ during dough ripening due to reduction of its gas-retention capacity.

Basing on the results of our study of dynamics of titratable acidity characterizing the dough test and check samples during ripening (Figure 3), we found that addition of 10 to $20 \%$ of maize germ oilcake leads to increase of dough initial acidity by 0.8 to $1.3 \mathrm{deg}$. This is connected with high acidity of the additive (Table 1). However, it is also worth to note that, during the experiment, change of this parameter in the dough with additive is more intensive: for $4 \times 60^{2} \mathrm{~s}$ of fermentation, the titratable acidity of the check sample is increased by $1.5 \mathrm{deg}$., and that of the dough sample with maize germ oilcake - by 1.9 to $2.5 \mathrm{deg}$., which is by 26.6 to $66.7 \%$ greater. This is connected with activation of vital activity of lactic acid bacteria due to a high content in the additive of the nutritional and biologically active substances required for their vital activity. 


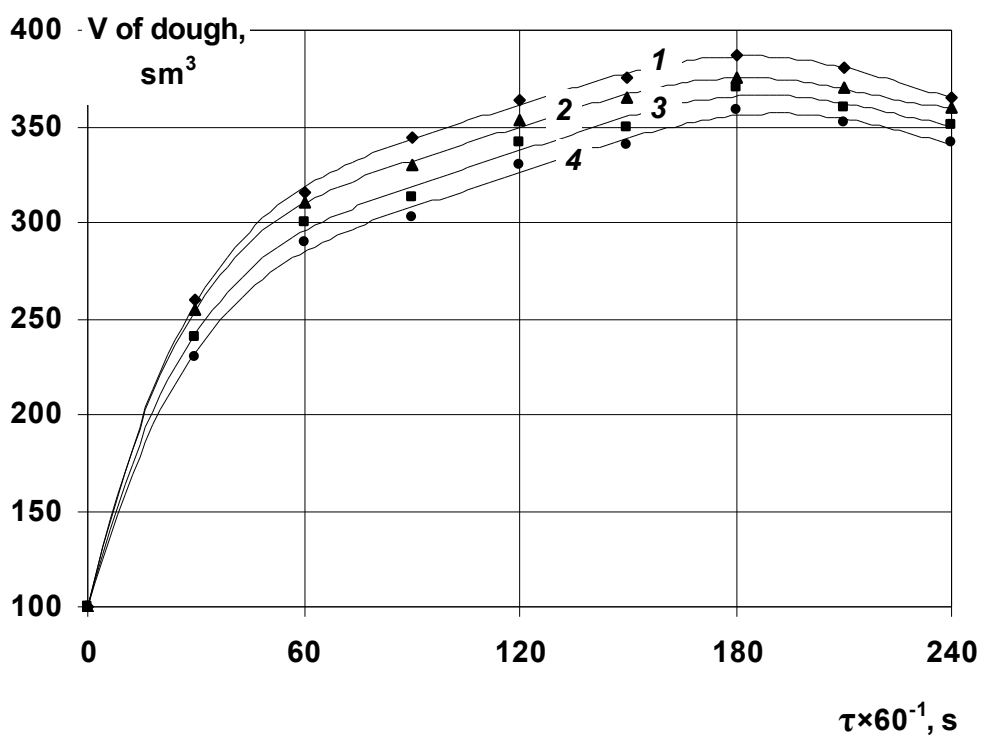

Figure 2. Change of volume in dough samples with maize germ oilcake: 1 - without additive (check sample);

$2,3,4$ - with introduction of $10.0 ; 15.0$ and $20.0 \%$ of additive, respectively

K, deg.



Figure 3. Change of titratable acidity in dough samples with maize germ oilcake: 1 - without additive (check sample); $2,3,4-2,3,4$ - with introduction of 10.0; 15.0 and $20.0 \%$ of additive, respectively 
Addition of maize germ oilcake during obtaining of wheat bread has also influence on organoleptic parameters of the baked bread quality. In particular, the products with maize germ oilcake, in comparison with the check sample, are characterized by brighter color of the crust, which, as the additive dosage increases, changes from light brown to brown. Besides, the bread gets a pleasant corn aftertaste and flavor, as well as yellowish color of its crumb.

The physical and chemical quality parameters of bread with the additive are presented in Table 2.

Table 2

Physical and chemical quality parameters of bread with maize germ oilcake

\begin{tabular}{|l|c|c|c|c|}
\hline \multirow{2}{*}{ Parameter } & \multicolumn{4}{|c|}{ Values of parameters of bread quality } \\
\cline { 2 - 5 } & $\begin{array}{c}\text { Check sample } \\
\text { (without } \\
\text { additive) }\end{array}$ & $\mathbf{1 0 , 0}$ & $\mathbf{1 5 , 0}$ & $\mathbf{2 0 , 0}$ \\
\cline { 3 - 5 } & $43.0 \pm 1.2$ & $43.9 \pm 1.2$ & $44.5 \pm 1.3$ & $44.9 \pm 1.3$ \\
\hline Moisture, \% & $2.8 \pm 0.1$ & $3.6 \pm 0.2$ & $3.9 \pm 0.2$ & $4.4 \pm 0.2$ \\
\hline Titratable acidity, deg. & $73.0 \pm 1.0$ & $71.0 \pm 1.0$ & $68.0 \pm 1.0$ & $64.0 \pm 1.0$ \\
\hline Porosity, \% & $3.0 \pm 0.1$ & $3.0 \pm 0.1$ & $2.8 \pm 0.1$ & $2.5 \pm 0.1$ \\
\hline Specific volume, $\mathrm{cm}^{3} / \mathrm{g}$ & \multicolumn{3}{|c}{} \\
\hline
\end{tabular}

From the data presented in the Table 2, it can be seen that the test samples have greater moisture content by 0.9 to $1.9 \%$, in comparison with the check sample. This is due to increase of dough calculated moisture, as well as to reduction of bread moisture release during baking at the expense of high content of highly hydrophilic polymers at the additive.

The values of titratable acidity of the test samples of bread are greater by 0.8 to $1.6 \mathrm{deg}$, than that of the check sample, which, on the one part, is connected with more intensive accumulation of acid in the dough with maize germ oilcake, and, on the other part, - with a higher titratable acidity of the additive itself, in comparison with wheat flour.

The porosity and specific volume of bread with introduced additive are decreased, which agrees with the results on change of dough volume presented above. In this case, the values of these parameters in the products with 10 and $15 \%$ of additive change substantially, and, in case of addition of $20 \%$ of germ oilcake they are reduced by 12.3 and $16.7 \%$, respectively. Therefore, manufacture of bread by straight method with such dosage is not expedient.

The results of nutritional and biological value assessment of bread are represented by products, which are made with addition of rational dosage of maize germ oilcake: that is $15.0 \%$ (Tables 3 and 4 ).

As can be seen from the data of Table 3, in case of introduction of $15 \%$ of the maize germ oilcake, the content in bread of protein and fat is inconsiderably increased and that of carbohydrates is decreased by $13.6 \%$.

The products with the said additive is a source of dietary fibers - their content is $4.3 \mathrm{~g}$ per $100 \mathrm{~g}$ of bread, which is by 1.7 times higher than that in the check sample.

The vitamin value of bread is increased substantially: in case of addition of maize germ oilcake, content of vitamin $\mathrm{B}_{1}$ in the products is increased by 1.4 times, vitamin $\mathrm{E}-$ by 3 times, PP - by1.2 times. Besides, in comparison with check sample, the bread samples have the content of calcium greater by 1.4 times, that of magnesium - by 2.2 times, phosphorus by 1.5 times and iron - by 2.3 times. 
Table 3

Content of nutritional and biologically active substances in bread with maize germ oilcake

\begin{tabular}{|l|c|c|}
\hline \multirow{2}{*}{ Parameter } & \multicolumn{2}{|c|}{$\begin{array}{c}\text { Content of nutritional and biologically active } \\
\text { substances in 100 g of bread }\end{array}$} \\
\cline { 2 - 3 } & $\begin{array}{c}\text { Without additive } \\
\text { (check sample) }\end{array}$ & $\begin{array}{c}\text { With 15\% of corn germ } \\
\text { pressed cake }\end{array}$ \\
\hline Proteins, $g$ & $7.3 \pm 0.3$ & $7.8 \pm 0.3$ \\
\hline Fats, $\mathrm{g}$ & $0.80 \pm 0.02$ & $1.30 \pm 0.04$ \\
\hline Carbohydrates, $\mathrm{g}$ & $50.6 \pm 2.0$ & $43.8 \pm 1.6$ \\
\hline Dietary fibers, $\mathrm{g}$ & $2.5 \pm 0.1$ & $4.3 \pm 0.1$ \\
\hline $\begin{array}{l}\text { Tanning substances (calculated } \\
\text { as tannin), mg/100g }\end{array}$ & $1.7 \pm 0.1$ & $18.1 \pm 0.9$ \\
\hline $\begin{array}{l}\text { Vitamins, mg } \\
\mathrm{B}_{1}\end{array}$ & $0.110 \pm 0.004$ & $0.150 \pm 0.006$ \\
\hline E & $0.88 \pm 0.02$ & $2.65 \pm 0.09$ \\
\hline PP & $1.37 \pm 0.05$ & $1.59 \pm 0.05$ \\
\hline $\begin{array}{l}\text { Mineral substances, mg: } \\
\text { Calcium }\end{array}$ & $13.2 \pm 0.6$ & $18.5 \pm 0.7$ \\
\hline Magnesium & $11.7 \pm 0.3$ & $25.9 \pm 1.1$ \\
\hline Phosphorus & $63.1 \pm 2.1$ & $93.3 \pm 3.7$ \\
\hline Iron & $0.90 \pm 0.02$ & $2.10 \pm 0.08$ \\
\hline
\end{tabular}

For determination of biological value of protein contained in the bread with maize germ oilcake, the amino acid score of unsubstituted amino acids was studied (Table 4). It is known that lysine is a limited amino acid in breadstuffs of wheat flour. The analysis of amino acid score of protein contained in bread with maize germ oilcake indicates increase of biological value of these products. In particular, it is important that content of lysine being deficient in wheat bread increased by $20.8 \%$, cystine and methionine - by $8.0 \%$, threonine - by $11.5 \%$.

Table 4

Biological value of proteins contained in bread with maize germ oilcake

\begin{tabular}{|l|c|c|}
\hline \multirow{2}{*}{\multicolumn{1}{|c|}{ Amino acid }} & \multicolumn{2}{|c|}{ Amino acid score of bread protein, \% } \\
\cline { 2 - 3 } & $\begin{array}{c}\text { Without additive } \\
\text { (check sample) }\end{array}$ & $\begin{array}{c}\text { With 15\% of corn } \\
\text { germ pressed cake }\end{array}$ \\
\hline Isoleucine & $120.6 \pm 3.8$ & $107.4 \pm 3.3$ \\
\hline Leucine & $111.8 \pm 3.6$ & $114.0 \pm 3.4$ \\
\hline Lysine & $49.0 \pm 1.2$ & $59.2 \pm 1.6$ \\
\hline Cystine + methionine & $98.0 \pm 3.0$ & $105.5 \pm 3.1$ \\
\hline Phenylalanine+ tyrosine & $113.2 \pm 3.4$ & $115.0 \pm 3.6$ \\
\hline Threonine & $70.7 \pm 2.1$ & $78.8 \pm 2.4$ \\
\hline Valine & $94.0 \pm 4.0$ & $90.0 \pm 3.6$ \\
\hline
\end{tabular}


The developed products are recommended to be used for traditional, health-giving prophylactic and therapeutic nutrition.

\section{Conclusions}

1. Substitution of wheat flour with $10.0-20.0 \%$ of maize germ oilcake leads to acceleration of microbiological processes in the dough, which makes it possible to shorten its ripening by 6.0 to $17.0 \%$.

2. To obtain bread with high organoleptic, physical and chemical quality parameters, using straight method of bread manufacture, it is expedient to use up to $15 \%$ of maize germ oilcake.

3. Introduction of $15 \%$ of the test additive leads to increase of content of unsubstituted amino acids, in particular that of lysine, as well as to increase of content of dietary fibers by 1.7 times, vitamins $B_{1}, E$ and $\mathrm{PP}$ by $1.4,3.0$ and 1.2 times, respectively, mineral substances: calcium, magnesium, phosphorus and iron by 1.4, 2.2, 1.5 and 2.3 times, respectively.

\section{References}

1. Oliinyk S.H., Stepankova H.V., Kravchenko O.I. (2015), Products of processing of oats and corn germs as promising raw materials in technology of breadstuffs, Kharchova nauka i tekhnolohiia, 9(3), pp. 62-68.

2. Hodunova L.Yu., Roiter Y.M. (1986), Use of wheat germs for enriching breadstuffs, Khlebopekarnaia, makaronnaia y drozhzhevaia promushlennost, 6(13), pp. 28.

3. Gomez M., Gonzales J., Oliete B. (2011), Effect of Extruded Wheat Germ on Dough Rheology and Bread Quality, Food and Bioprocess Technology, Available at: http://www.springerlink.com/ content/t85032810 r285844/.

4. Kravchenko O.I., Lysiuk H.M., Oliinyk S.H. (2010), Use of dietary additive «Pressed cake of food-grade wheat» for increase of bread nutritional value, Zbirnyk naukovykh prats Odeskoi natsionalnoi akademii kharchovykh vyrobnytstv, pp. 195-200.

5. Arsen'eva L.Yu., Arsinenko N.A., Salivon M.S. (2010), Creation of bread having increased nutritional value, Materialy 3-j Vserossijskoj nauchno-prakt. konf. studentov, aspirantov i molodyh uchenyh, pp. 107-112.

6. Oliinyk S.H.,Stepankova H.V. (2014), Influence of products obtained during processing oats and corn on structural and mechanical properties of wheat flour dough, Scientific Leters of Academic Society of Michail Baludansky, 2(5), pp. 76-80.

7. Drobot V.I. (2015), Technical control of raw materials, as well as bread and noodle products, Kondor, Kyiv.

8. Lawless H., Heymann, H. (1999), Organoleptic Evaluation of Food, Springer Science+Business Media, New York.

9. Nielsen S.S. (2010), Food Analysis (Food Science Texts Series), Springer Science+Business Media, West Lafayette, IN, USA.

10. Greene J.L., Bovell-Benjamin A.C. (2004), Macroscopic and organoleptic evaluation of bread supplemented with sweet potato flour, Journal Food Sci., 69, pp. 167-173.

11. Drobot V.I., Arsenieva L.Yu., Bilyk O.A. (2006), Laboratory practical course in technology of bread and noodle manufacture, Tsentr navchalnoi literatury, Kyiv. 
12. Căpriţă R., Căpriţă A. (2011), Chemical Methods for the Determination of Soluble and Insoluble Non-Starch Polysaccharides - Review, Scientific Papers: Animal Science and Biotechnologies, 44(2), pp. 73-80.

13. Nelsen S.S. (2003), Food Analysis (Food Science Texts Series), Toledo, OH, U.S.A.

14. Mondal K.C., Banerjee D., Jana M., Pati B.R. (2001), Colorimetric Assay Method for Determination of the Tannin Acyl Hydrolase (EC 3.1.1.20) Activity, Analytical Biochemistry, 295(2), pp. 168-171.

15. Ollilainen V., Vahteristo L., Uusi-Rauva A., Varo P., Koivistoinen P., Huttunen J. (1993), The HPLC Determination of Total Thiamin (Vitamin $B_{1}$ ) in Foods, Journal of Food Composition and Analysis, 6(2), pp. 152-165.

16. Brabcová I., Kováŕová L., Šatínský D., Havlíková L., Solich P. (2012), A Fast HPLC Method for Determination of Vitamin E Acetate in Dietary Supplements Using Monolithic Column, Food Analytical Methods, 6(2), pp. 380-385.

17. Schmitt S, Garrigues S, de la Guardia M. (2014), Determination of the mineral composition of foods by infrared spectroscopy: a review of a green alternative, Critical Reviews in Analytical Chemistry, 44(2), pp. 186-197. 